\title{
PREPARATION OF CHATURTHAMALAKA RASAYANA, A CLASSICAL FORMULATION IN
} CHARAKA SAMHITA

Gajarmal Amit Ashok ${ }^{* 1}$, Sudipt Rath ${ }^{2}$

${ }^{1} \mathrm{PhD}$ (Sch), Research Officer (Ayu.), Central Council for Research in Ayurvedic Sciences (CCRAS), , Ministry of AYUSH, Govt. of India, Janakpuri, New Delhi, India

${ }^{2}$ Assistant Professor, Post-Graduation Department of Dravyagunavigyana, National Institute of Ayurveda (NIA), Jorawar Singh Gate, Jaipur, Rajasthan, India

Received on: 28/03/19 Accepted on: 22/05/19

\author{
*Corresponding author \\ E-mail: dgalaxy78@gmail.com
}

DOI: $10.7897 / 2277-4343.100363$

\section{ABSTRACT}

Introduction: Ayurveda, the oldest traditional healthcare system gives utmost importance to the prevention of diseases by adopting a healthy lifestyle and restoration of health through Rasayana (Rejuvenation therapy). In various texts of Ayurveda, n number of formulations has been mentioned as Rasayana therapies. Out of this, the formulation mentioned after Chyavanprasha Avaleha in classical text is 'Chaturthamalaka Rasayana', which was selected for the study. Its classical preparation methodology quoted for four different combinations of ingredients were practically explored with the aim to provide a standardization strategy for forthcoming preparations. Methods: Initially, we collected all the raw ingredients in fresh form and then they were authenticated and further standardized as per the classical and modern parameters. The formulations were prepared by strictly adhering to the instructions mentioned in the classical text for each and every step. Result and discussion: When we practically prepared these formulations by adopting the classical methodology, we encountered few difficulties in its preparation and we forced to make few alterations which are addressed in this paper. Conclusion: The preparation of 'Chaturthamalaka Rasayana' by the classical method theoretically seems to be very easy, but practically we have to make extra efforts and alterations so that we can get a good quality product. However, it can also be served as a cost-effective alternative to many other Rasayanas like Chyavanaprasha.

KEY WORDS: Ayurveda, Rasayana, Chaturthamalaka, Chyavanprasha, Charaka

\section{INTRODUCTION}

Ayurveda is the science of life. It is also popularly known as an ancient Indian traditional healing science. Now a days, as technologies get advanced, modern medicine can provide results for the prevention and cure of diseases, but they are complicated and unsatisfactory. One of the best answer is hidden in Ayurveda i.e. Rasayana (Rejuvenation therapy). The term Rasayana is a compound word comprising of two words, 'Rasa' and 'Ayana'. Rasa is derived from the verb root 'Rasa' in the sense of Gati (movement) and thus rasa is so called as it moves constantly ${ }^{1}$. In present context of Rasayana, the word Ayana has the sense of attainment. Thus the term Rasayana is a compound word which denotes the process of attaining Ahara Rasa (nutrition) of good quality for the body.

In Charaka Samhita, Chyavanprasha ${ }^{2}$ is mentioned, which is one of the popular and commonly used Rasayana formulation. Just after this, Chaturthamalaka Rasayana ${ }^{3}$ is mentioned which has equal benefits, as same as Chyavanprasha. The method of preparation of Chaturthamalaka Rasayana is unique, which substantiates the knowledge of alchemy prevailing in ancient India. Also after online search of articles and reviewing past Rasayana based thesis works, it seems that no one yet studied it before. So we decided to attempt its preparation according to classical text.

\section{Drug Preparation}

Chaturthamalaka Rasayana having permutation-combination of three simple Dravyas (material) with four Yoga (combinations) which has property of enhancing the immunity of body and its assumed to keep man healthy alive up to several centuries ${ }^{3}$. Chaturthamalaka Rasayana has total nine ingredients in the preparation as per listed in table 1 .

Table 1: Ingredients of Chaturthamalaka Rasayana

\begin{tabular}{|c|c|c|c|c|c|}
\hline Sr. No. & Dravya & English Name & Latin Name & Family & Part used \\
\hline 1. & Amalaki & Indian gooseberry & Emblica officinalis Gaertn & Euphorbiaceae & Fruit \\
\hline 2. & Haritaki & Chebulic myrobalan & Terminalia chebula Retz. & Combretaceae & Fruit \\
\hline 3. & Bibhitaki & Belleric myrobalan & Terminalia bellerica Roxb & Combretaceae & Fruit \\
\hline 4. & Dadhi & Curd & - & - & - \\
\hline 5. & Madhu & Honey & - & - & - \\
\hline 6. & Ghrita & Ghee & - & - & - \\
\hline 7. & Tila Palala (Kalka) & Sesame paste & Sesamum indicum Linn. & Pedaliaceae & Seed \\
\hline 8. & Tila Tailam & Sesame oil & Sesamum indicum Linn. & Pedaliaceae & Oil \\
\hline 9. & Sharkara & Sugar & - & - & \\
\hline
\end{tabular}




\section{Collection of raw drugs}

Fresh fruits of Amalaki \& Bibhitaki were self-collected from Amboli Ghat, Konkan Region, Dist. Sindhudurga, Haritaki from Bhimashankara, Dist. Pune, Maharashtra state. Tila and other remaining ingredients were collected from Jaipur, Rajasthan, in the month of January, after proper identification. All the collected raw materials used in the preparation of Chaturthamalaka Rasayana are in Fig 1.

The collected sample of Amalaki fruit found to be, having wt. of an average $27 \mathrm{gm}$. For the Bibhitaki, as per mentioned in the

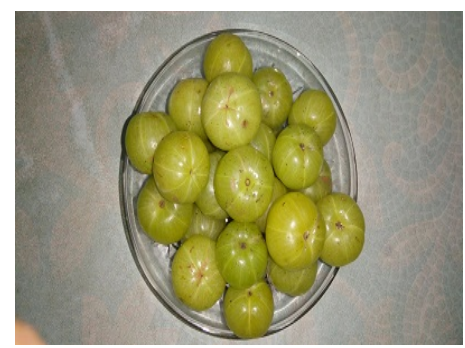

Amalaki Ardra Phala

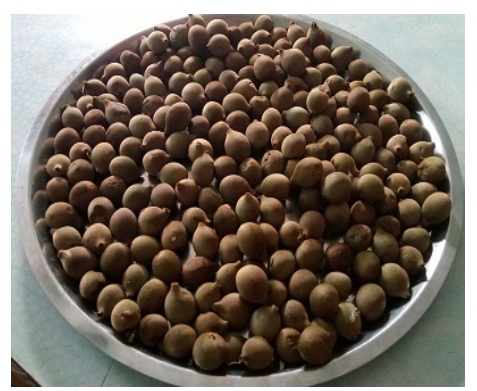

Bibhitaki Ardra Phala

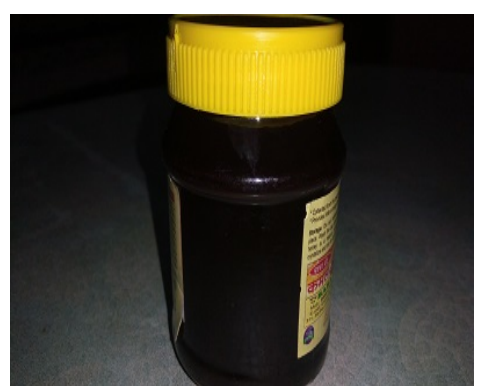

Madhu

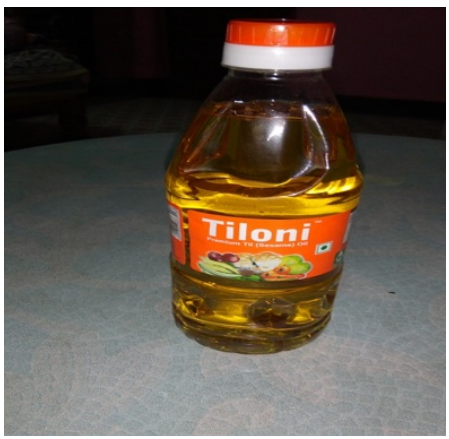

Tila Tailam classics, average weight should be $1 \mathrm{Karsha}^{4}$ and the collected sample found to be having an average weight of $8 \mathrm{gm}$. For Haritaki, an average weight should be Dwikarshita and the collected sample found to be having an average weight of $18 \mathrm{gm}$. Ghana and Gurvi parameters of Haritaki were found prominent and all the samples of Haritaki when put down in the water sinks at basement proved they possess Jala Nimajjana parameter ${ }^{5}$. All the fresh raw drug samples were identified and authenticated by Mr.Amit Kotiya (specialisation in plant taxonomy and ecology), assistant professor, under the direction of the convener of the herbarium committee held at the department of Botany, University of Rajasthan, Jaipur.

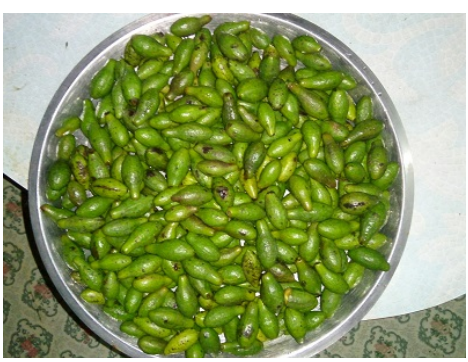

Haritaki Ardra Phala

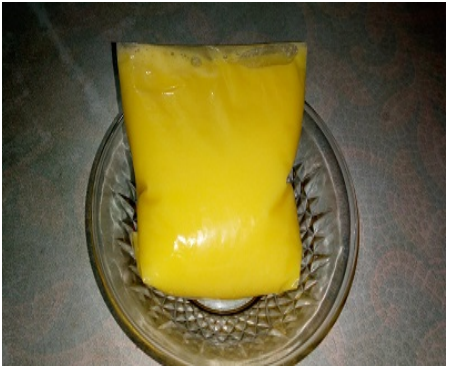

Ghrita

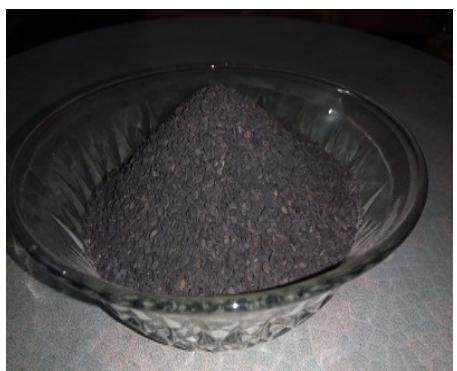

Tila (Krishna)

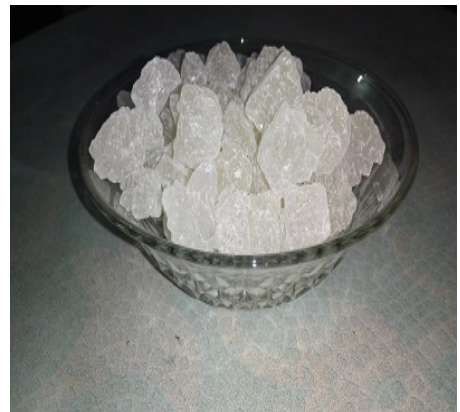

Sharkara 


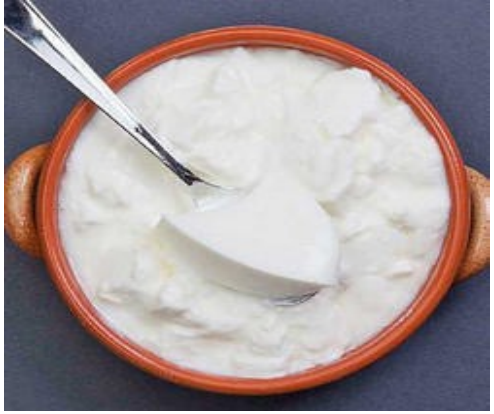

Dadhi

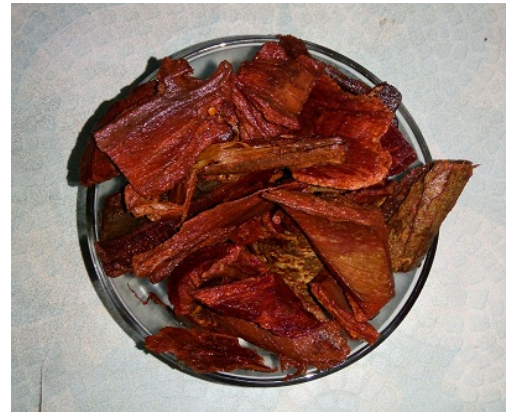

Palasha Twaka

Fig 1: Raw Materials used in the preparation of Chaturthamalaka Rasayana

\section{Classical method of Chaturthamalaka Rasayana preparation $^{6}$}

After attempting 3 trails, we got the final steps as per classical text. In previous few attempts, the number of Upala (cow dung cake) makes the fresh fruit over cooked or under cooked. So after minimizing previous errors, we considered to using the middle sized 8-10 Upala along with Madhyamagni (moderate fire). After authentication of raw drugs, they were washed \& cleaned properly. [Ardra Dravya Sankalana]. Then we took them in the alternate combinations as, [A] Amalaki + Haritaki, [B] Amalaki + Bibhitaki [C] Haritaki + Bibhitaki [D] Amalaki + Haritaki + Bibhitaki. Then all of the samples were wrapped with stem of Palasha (Tvaka) with source Butea monosperma Linn. and then covered with mud (Mrittika Lepana) up to thickness of Anguli Pramana (approximately 2-2.5cm $)^{7}$. [Mrida Avalipta]. Then kept in sunlight for 5-6 hrs for drying. This dried mud balls were roasted in the fire generated by Upala [Kukulake Swinna] up to it gets hot around 45 minutes. After that it was allow to cool little bit and upper coating of balls were removed. The steamed fruits were collected. The pulp and seeds were separated and only pulp was taken to prepare a paste by mortar and pestle [Ulukhale Sampothha]. Equal quantity of Ghrita, Tila Pishti, Tila Tailam and Sharkara were added together in the above prepared four combinations and mild heat was given just to evaporate the extra moisture. After that it was allowed to cool. After cooling, Madhu was added in a quantity discussed before and the whole prepared mixture packed in air tight containers [Dadhi-Ghrita-MadhuPalala-Taila-Sharkara Samyuktam]. Dadhi is one of the ingredient of the formulations, due to its nature mostly it will reduce the stability and self-life of the test drug formulation. Therefore it was planned to prepare the test drugs without adding Dadhi, which were added later only at the time of experimental studies.

In this way, the four test drugs were prepared and labelled as test drug I, II, III, IV. The raw drugs were taken in a quantity such that they were in the proportion mentioned in the classical reference. (Table 2 and Fig 2)

Table 2: Quantity of raw drugs in the preparation of Chaturthamalaka Rasayana

\begin{tabular}{|c|c|c|c|c|c|}
\hline Sr.No. & Dravya & Test drug I & Test drug II & Test drug III & Test drug IV \\
\hline 1. & Amalaki (Swinna) & $125 \mathrm{gm}$ & $125 \mathrm{gm}$ & -- & $100 \mathrm{gm}$ \\
\hline 2. & Bibhitaki (Swinna) & -- & $125 \mathrm{gm}$ & $125 \mathrm{gm}$ & $100 \mathrm{gm}$ \\
\hline 3. & Haritaki (Swinna) & $125 \mathrm{gm}$ & - & $125 \mathrm{gm}$ & $100 \mathrm{gm}$ \\
\hline \multicolumn{2}{|c|}{ Total Pulp (wt.) } & 250gm & 250gm & 250gm & 300gm \\
\hline 4. & Ghrita & $250 \mathrm{gm}$ & $250 \mathrm{gm}$ & $250 \mathrm{gm}$ & $300 \mathrm{gm}$ \\
\hline 5. & Madhu & $250 \mathrm{gm}$ & $250 \mathrm{gm}$ & $250 \mathrm{gm}$ & $300 \mathrm{gm}$ \\
\hline 6. & Tila & $250 \mathrm{gm}$ & $250 \mathrm{gm}$ & $250 \mathrm{gm}$ & $300 \mathrm{gm}$ \\
\hline 7. & Tila Tailam & $250 \mathrm{gm}$ & $250 \mathrm{gm}$ & $250 \mathrm{gm}$ & $300 \mathrm{gm}$ \\
\hline 8. & Sharkara & $250 \mathrm{gm}$ & $250 \mathrm{gm}$ & $250 \mathrm{gm}$ & $300 \mathrm{gm}$ \\
\hline \multicolumn{2}{|c|}{ Test drug (wt.) } & $1500 \mathrm{gm}$ & $1500 \mathrm{gm}$ & $1500 \mathrm{gm}$ & $1800 \mathrm{gm}$ \\
\hline 9. & Dadhi & ed in an & ne & stituents, & f examina \\
\hline
\end{tabular}

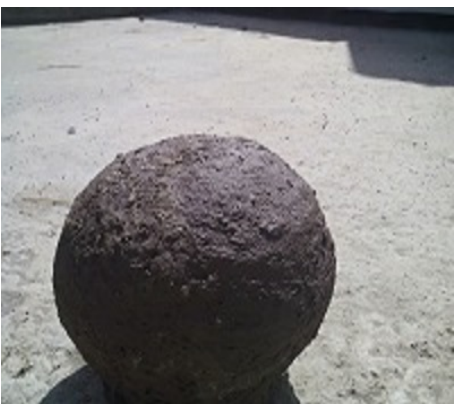

1.Mruda Avalipta

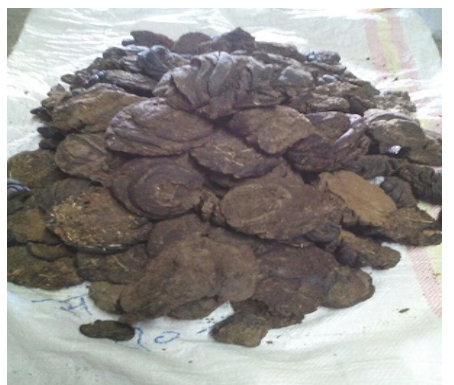

2.Kukula (Upala) 


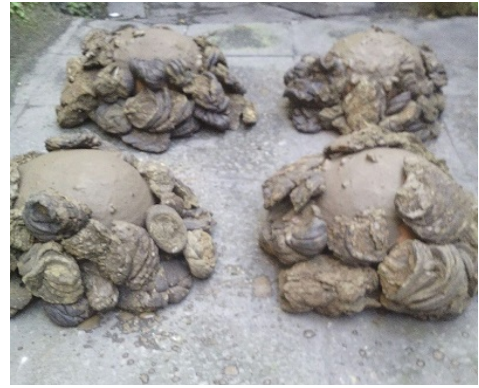

3.Kukula (Upala)

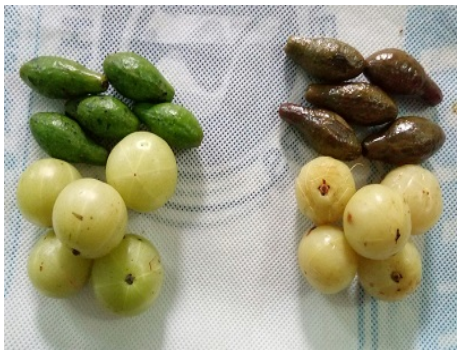

5.Amalaki + Haritaki Phala

(Lt. Ardra and Rt. Swinna)

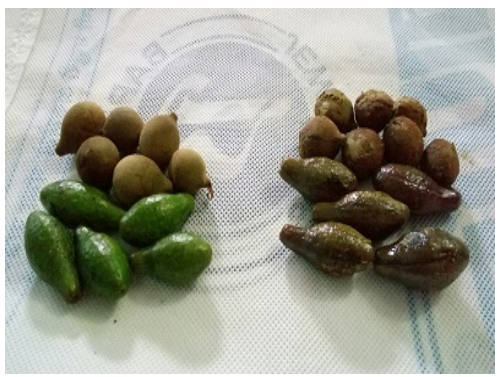

7.Bibhitaki + Haritaki Phala (Lt. Ardra and Rt. Swinna)

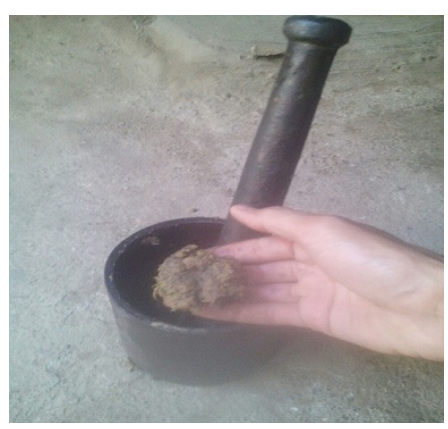

9.Ulukhale Sampothha

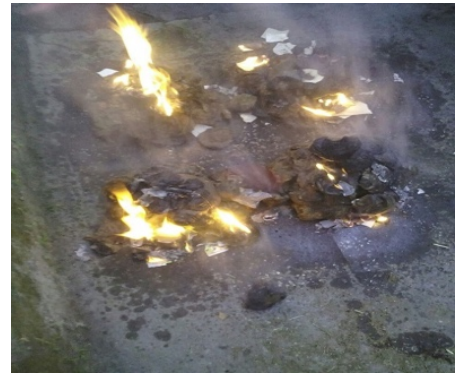

4.Putapaka

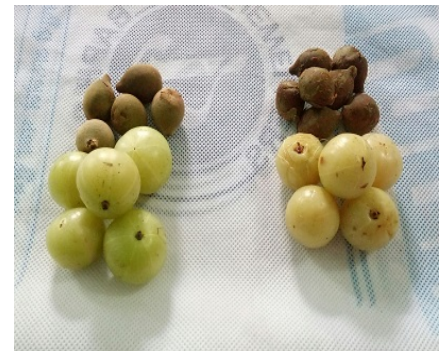

6.Amalaki + Bibhitaki Phala

(Lt. Ardra and Rt. Swinna)

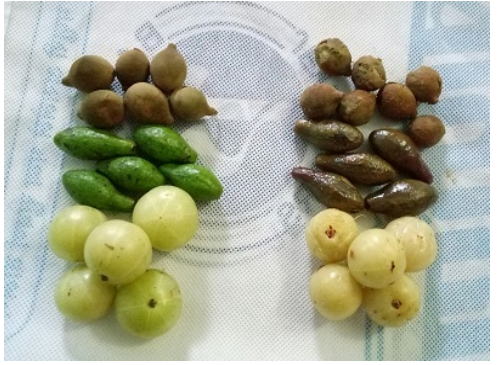

8.Amalaki+Haritaki+Bibhitaki Phala (Lt. Ardra and Rt. Swinna)

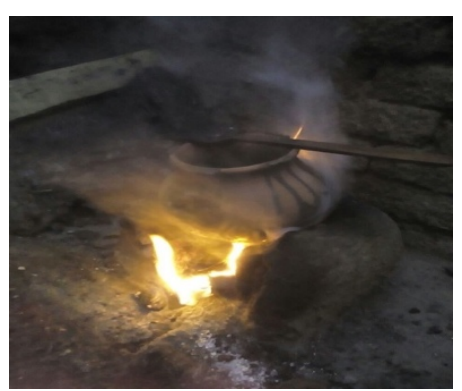

10.Agnipaka 


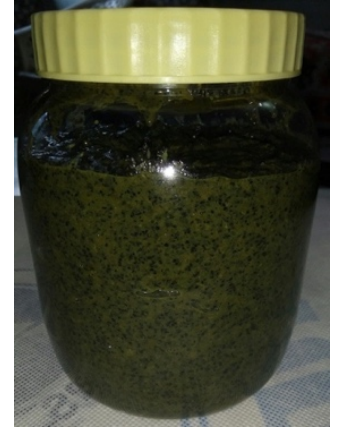

11.Test drug I

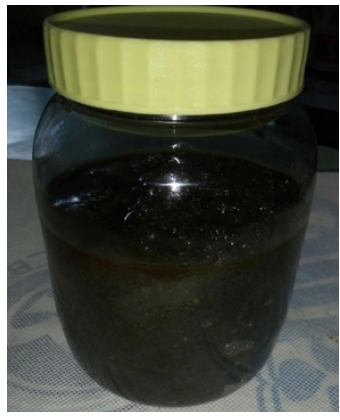

12.Test drug II

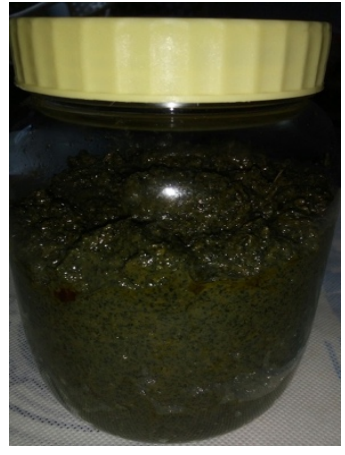

13.Test drug III

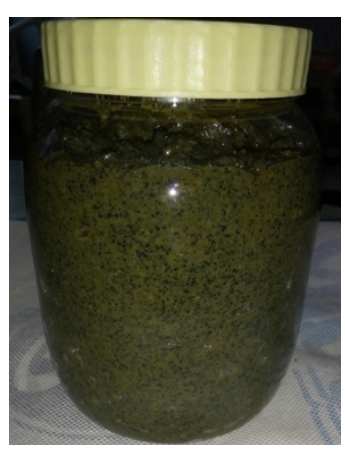

14. Test drug IV

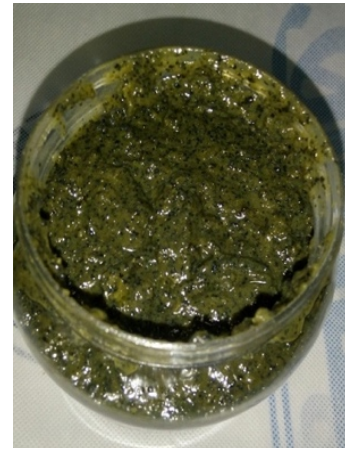

11(a).Test drug I

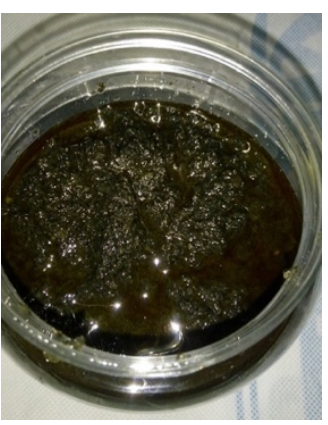

12(a).Test drug II

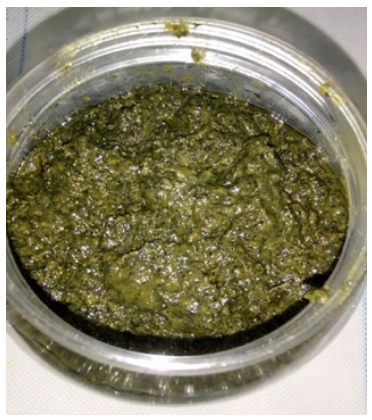

13(a).Test drug III

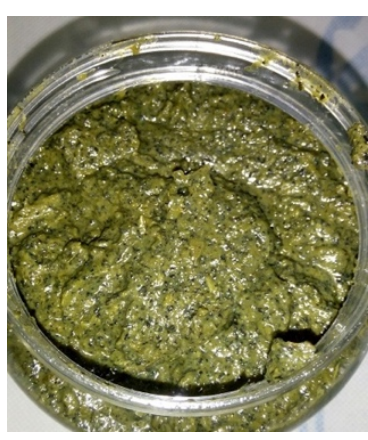

14(a). Test drug IV 


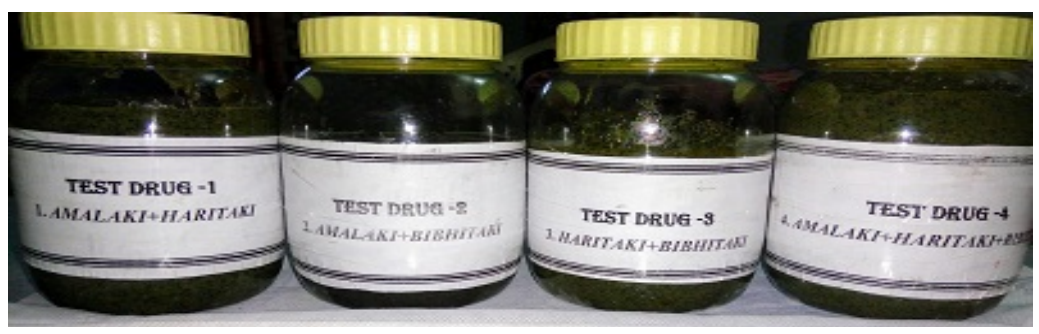

15. Final Test drugs I, II, III and IV

Fig 2: Chaturthamalaka Rasayana Nirmana Vidhi (Drug preparation)

\section{RESULTS AND DISCUSSION}

The quest of man to live longer periods and remain healthy as large as alive, has laid to a fanatic search for miracle or remedies that may produce the desired results. To accomplish the best health, with delayed aging system is also a most desirable thing, even within the life span set by the genetic pattern. For this goal 'Rasayana' are mentioned in Ayurveda, which bestows excellent Rasa, ultimately results in promotion of longevity, alleviation of old age and diseases. Rasayana therapy works at the level of Rasa (nutrition), Agni (Digestion \& metabolism), Strotasa (microcirculation) enabling the organism to procure the best quality of different Dhatus (seven primitive factors). Prabhava (exceptional activity) of Rasayana Dravya results in achievement of certain divine effects as well.

On the other hand, to prove the Rasayana effects scientifically, there should be various lab experiments as well as clinical trials of this Rasayana formulation. In a trial, selection of a drug is a milestone because success of the project totally depends on that. Trial drug should be effective, safe, economic, with easily available samples and easy for preparation and administration as well. To fulfil all these criteria. Chaturthamalaka Rasayana might be considered as one of the best formulation which has to be prepared by classical methods to verify its classical claims. In the preparation of Chaturthamalaka Rasayana, we followed the exact classical steps mentioned in Charaka Samhita. The quantity of Swinna Phala (stemmed fruit pulp of Amalaki, Haritaki and Bibhitaki) has been mentioned to be take in a quantity of
Palasahastram $(1$ Pala $=40 \mathrm{gm})$. The quantity of other raw drugs like Dadhi, Tila Palala, Madhu etc was not mentioned. We took less quantity of a Swinna Phala and by applying the rule of Anukta Pramana $^{8}$, we also took the remaining raw drugs in an equal quantity that of the quantity of total pulp per formulation. Initially, the quantity we decided to take was just for considering the experimental study and not for the commercial purpose. One might be take the quantity of raw drug pulp as much as he wants and the remaining raw drugs same in an equal quantity that of the pulp. In such way we prepared test drugs I, II, III and IV as per classical methods.

The Gandha (odour), Varna (color), Rasa (taste) etc. of the drug in the final product indicates the proper extraction of drugs. On organoleptic examination we observed that, the best drug I, III and IV shows greenish brown colour with non-specific unpleasant odour and with sour-sweet followed by bitter in taste while test drug II shows brownish black colour, odour of Ghrita, sour-sweet followed by astringent taste. A drug (Dravya) performs certain actions (Karma) in the body by virtue of its properties called as Rasapanchaka i.e. Guna (properties), Rasa (taste), Virya (potency), Vipaka (metabolism) and Prabhava, which is available in it in a state of co-inherence (Table 3). Uniformity of proto-elements of the drug on one hand and the proto-elemental constituents of the body on the other hand forms the basis of the Samanya-Vishesha Siddhanta (principle). These principles suggest that the predominant proto-elements of the drug will increase similar proto-elements in the body and the dissimilar will decrease the proto-elements.

Table 3: Rasapanchaka of contents of Chaturthamalaka Rasayana

\begin{tabular}{|c|c|c|c|c|c|c|}
\hline Sr. No. & Dravya & Rasa & Vipaka & Virya & Guna & Karma/Prabhava \\
\hline 1. & Amalaki & $\begin{array}{c}\text { Pancharasa (Lavana } \\
\text { Varjita) }\end{array}$ & Madhura & Shita & Guru, Ruksha & Rasayana $^{9}$ \\
\hline 2. & Haritaki & $\begin{array}{c}\text { Pancharasa (Lavana } \\
\text { Varjita) }\end{array}$ & Madhura & Ushna & Laghu, Ruksha & Rasayana $^{10}$ \\
\hline 3. & Bibhitaki & Kashaya & Madhura & Ushna & Laghu, Ruksha & Netrya, Keshya, Vaisvaryanashana $^{11}$ \\
\hline 4. & Dadhi & Amla, Kashaya & Amla & Ushna & Guru, Snigdha & Dipana, Hridya, Pushtikrita $^{12}$ \\
\hline 5. & Madhu & Madhura, Kashaya & Katu & Shita & Laghu, Ruksha & Yogavahi, Chedana, Lekhana $^{13}$ \\
\hline 6. & Ghrita & Madhura & Madhura & Shita & Guru, Snigdha & Rasayana, Dipana, Netrya ${ }^{14}$ \\
\hline 7. & Tila & $\begin{array}{l}\text { Katu, Tikta, Madhura, } \\
\text { Kashaya }\end{array}$ & Katu & Ushna & Guru, Snigdha & $\begin{array}{c}\text { Balya, Keshya, Agnivardhaka, } \\
\text { Medhya }^{15}\end{array}$ \\
\hline 8. & Tila Tailam & Madhura, Kashaya, Tikta & Madhura & Ushna & Guru, Snigdha & Bala Varnakaraka, Vrishya, Dipana $^{16}$ \\
\hline 9. & Sharkara & Madhura & Madhura & Shita & $\begin{array}{l}\text { Laghu, } \\
\text { Snigdha }\end{array}$ & $\begin{array}{c}\text { Brihana, Vata-Rakta Pitta-Daha } \\
\text { Shamana, Netrya }{ }^{17}\end{array}$ \\
\hline
\end{tabular}

We used Amalaki with source Emblica officinalis Gaertn. which was easily available, get steamed easily and gives maximum quantity of pulp. Someone might be taking the variety of Amalaki with source Phyllanthus acidus (L.) Skeels ${ }^{18}$, locally known as Rai Amla (Country Gooseberry), for the experimental point of view. Also one may be experimentally utilized modern cooking tools in the preparation of Chaturthamalaka Rasayana especially for steaming with fresh fruit and may be compared with the final preparations for those with made by classical textual methods.

All the ingredients of the Chaturthamalaka Rasayana show those properties which give overall benefits to keep a healthy life mentioned in Table 3. In Charaka Samhita, as Chaturthamalaka Rasayana comes just after Chyavanprasha which is an Avaleha, it seems that Chaturthamalaka Rasayana also resembles in the form 
of Avaleha. From the above all discussion, we consider Chaturthamalaka Rasayana as a one of the alternative to Chyavanprasha.

\section{CONCLUSION}

Now a day, there are many popular market products sold in the name of nutraceuticals worldwide which contain vitamins, fats, proteins, carbohydrates, minerals as well as active principles that act in diseases. Chyavanaprasha Avaleha is a popular preparation which can be considered as a nutraceutical and has huge annual turnover in the market but simultaneously it has issues of adulteration and cost also. Now a day, the Dashamula with forty ingredients of Chyavanprasha are not readily available. To overcome all these issue, Chaturthamalaka Rasayana is one of the best alternative options in the form of Avaleha. It can be compared with nutraceutical but not with functional food or dietary supplement. Generally it was found that, Avaleha contains proteins, carbohydrates, minerals, vitamins and fats with pharmacologically active substances. Similarly we may explore the Chaturthamalaka Rasayana maximum potential if one follows classical methods of preparation absolutely. In future, It will be an area of research to compare the Chaturthamalaka Rasayana, prepared with classical methods and those with prepared by using modern cooking tools.

\section{REFERENCES}

1. Yadavji Trivikramji Acharya. Sutrasthana Patham Adhyaya, verse 15. Ram Narayan Acharya (ed). Sushruta Samhita of Sushruta with Nibandha Samgraha commentary, 7 ed. Varanasi: Chaukhamba Orientalia; 2002. pp. 62.

2. Bramhanand Tripathi. Charaka Samhita. Varanasi: Chaukhamba Prakashana; 2008. Chikitsasthana Pratham Adhyaya Pratham Pada, verse 62-74. pp. 13-14.

3. Bramhanand Tripathi. Charaka Samhita. Varanasi: Chaukhamba Prakashana; 2008. Chikitsasthana Pratham Adhyaya Pratham Pada, verse 75. pp. 14.

4. P.V. Sharma. Chedanadi Varga. Dravyaguna Vigyana Dvitiya Bhaag. Varanasi: Chaukhambha Bharati Academy; 2006. pp. 239.

5. K. C. Chunekar. Haritakyadi Varga, verse 25-26. G. S. Pandey (ed). Bhavprakasha Nighantu (Indian Materia Medica) of Sri Bhavamishra, 10th ed. Varanasi: Chaukhamba Bharti Academy; 1995. Reprint: 2010. pp. 5.

6. Bramhanand Tripathi. Charaka Samhita. Varanasi: Chaukhamba Prakashana; 2008. Chikitsasthana Pratham Adhyaya Pratham Pada, verse 75. pp. 14.

7. Ashwini Patil and Mushraf R. Sayyad. A Literature Review on Pramana (Ayama-Vistara) Pariksha with Special Reference to Anthropometry. ADJIM 2018; 3(3): http://www.ayurveddarpan.com/AyurVed/journal/96_1.pdf (accessed 25 Feb 2019).
8. Ketki Chatuphale (Aurangabadkar). Concept of Anukta according to Ayurveda. World journal of pharmaceutical and medical research 2018; 4(4). pp. 317-319. https://www.wjpmr.com/download/article/33032018/152473 4595.pdf (accessed $27 \mathrm{Feb} 2019$ ).

9. K. C. Chunekar. Haritakyadi Varga, verse 39. G. S. Pandey (ed). Bhavprakasha Nighantu (Indian Materia Medica) of Sri Bhavamishra, $10^{\text {th }}$ ed. Varanasi: Chaukhamba Bharti Academy; 1995. Reprint: 2010. pp. 10.

10. K. C. Chunekar. Haritakyadi Varga, verse 19. G. S. Pandey (ed). Bhavprakasha Nighantu (Indian Materia Medica) of Sri Bhavamishra, $10^{\text {th }}$ ed. Varanasi: Chaukhamba Bharti Academy; 1995. Reprint: 2010. pp. 4.

11. K. C. Chunekar. Haritakyadi Varga, verse 35-37. G. S. Pandey (ed). Bhavprakasha Nighantu (Indian Materia Medica) of Sri Bhavamishra, $10^{\text {th }}$ ed. Varanasi: Chaukhamba Bharti Academy; 1995. Reprint: 2010. pp. 9.

12. K. C. Chunekar. Dadhi Varga, verse 10. G. S. Pandey (ed). Bhavprakasha Nighantu (Indian Materia Medica) of Sri Bhavamishra, $10^{\text {th }}$ ed. Varanasi: Chaukhamba Bharti Academy; 1995. Reprint: 2010 pp. 751.

13. K. C. Chunekar. Haritakyadi Vargam, verse 1-5. G. S. Pandey (ed). Bhavprakasha Nighantu (Indian Materia Medica) of Sri Bhavamishra, $10^{\text {th }}$ ed. Varanasi: Chaukhamba Bharti Academy; 1995. Reprint: 2010. pp. 772.

14. K. C. Chunekar. Haritakyadi Varga, verse 4-6. G. S. Pandey (ed). Bhavprakasha Nighantu (Indian Materia Medica) of Sri Bhavamishra, $10^{\text {th }}$ ed. Varanasi: Chaukhamba Bharti Academy; 1995. Reprint: 2010. pp. 758.

15. K. C. Chunekar. Haritakyadi Varga, verse 63-65. G. S. Pandey (ed). Bhavprakasha Nighantu (Indian Materia Medica) of Sri Bhavamishra, $10^{\text {th }}$ ed. Varanasi: Chaukhamba Bharti Academy; 1995. Reprint: 2010. pp. 638-639.

16. K. C. Chunekar. Haritakyadi Varga, verse 2-7. G. S. Pandey (ed). Bhavprakasha Nighantu (Indian Materia Medica) of Sri Bhavamishra, $10^{\text {th }}$ ed. Varanasi: Chaukhamba Bharti Academy; 1995. Reprint: 2010. pp. 763.

17. K. C. Chunekar. Haritakyadi Varga, verse 29.G. S. Pandey (ed). Bhavprakasha Nighantu (Indian Materia Medica) of Sri Bhavamishra, $10^{\text {th }}$ ed. Varanasi: Chaukhamba Bharti Academy; 1995. Reprint: 2010. pp. 780.

18. Khare C.P. Indian Medicinal Plants - An Illustrated Dictionary. Berlin/Heidelberg: Springer-Verlag; 2007. pp. 481.

\section{Cite this article as:}

Gajarmal Amit Ashok and Sudipt Rath. preparation of chaturthamalaka rasayana, A classical formulation in Charaka samhita. Int. J. Res. Ayurveda Pharm. 2019;10(3):59-65 http://dx.doi.org/10.7897/2277-4343.100363

Disclaimer: IJRAP is solely owned by Moksha Publishing House - A non-profit publishing house, dedicated to publish quality research, while every effort has been taken to verify the accuracy of the content published in our Journal. IJRAP cannot accept any responsibility or liability for the site content and articles published. The views expressed in articles by our contributing authors are not necessarily those of IJRAP editor or editorial board members. 